\section{Лілія HEBAPA}

\section{Підходи до екологічної освіти}

\begin{abstract}
У статті розглядається міжнародно-правове регулювання питань екологічної освіти. Автор досліджує і детально аналізує особливості розвитку проблем екології протягом десятиліть та підходи до екологічної освіти різних держав, зокрема і України. Автор проаналізував погляди на проблему екологічної освіти та захист навколишнього середовища представників релігіі.
\end{abstract}

Ключові слова: екологічна освіта, екологічна інформація, концепція сталого розвитку, навколишнє середовище.

The article analyses international treaties and other sources in which the problems of ecology are identified and the need to integrate ecological education into the whole system of formal and informal education at all levels. The concept of environmental protection and the need for ecological education by representatives of religion are presented. It is noted that this integrated approach forms the basis for the further development of environmental education, in particular in Ukraine, covering the most widespread areas of society, allowing the public to be involved in this issue.

Key words: environmental education, environmental information, sustainable development concept, environment.

На сучасному етапі ефективного розвитку і глобалізації міжнародних відносин у сфері екологічного права перед світовим співтовариством продовжує поставати проблема забруднення навколишнього середовища, що найчастіше проявляється у викиді у водойми токсичних промислових відходів, забрудненні атмосфери шкідливими речовинами, а також активному використанню поліетилену та пластику в повсякденному житті. Ці фактори негативно впливають не лише на навколишнє середовище, а й на здоров'я всього людства. Задля запобігання катастрофічного впливу на екологію необхідно, перш за все, покращити ефективність екологічної освіти.

Першим головним результатом у сфері екології стало заснування у 1970 р. Національної Асоціації Екологічного навчання (нині - Північна Асоціація Екологічної освіти), основною метою якої була розробка та впровадження нових загальноосвітніх програм з екології.

У 1971 році «блаженний Папа Павло VI звернувся до проблеми екології, представивши ії як кризу 3 трагічними наслідками через безконтрольну діяльність людини: «Бездумною експлуатацією природи вона ризикує зруйнувати іiі і опинитися, в свою чергу, жертвою цього знищення» [1, с. 7; 2]. Він проголошував необхідність зміни ставлення людини до природи, зменшення індустріалізації та технічного розвитку суспільства, що, на його погляд, може призвести до негативних наслідків для людства.

Більшість вчених та філософів XX століття розглядали проблему екологічної освіти через призму релігії та моралі. Так, Патріарх Варфоломій стверджував, що «в тій мірі, в якій всі ми наносимо певний збиток екології, ми покликані визнавати наш вплив - будь то малий чи великий - на псування і руйнування навколишнього середовища» [1, с. 10; 3]. А Святий Іоанн Павло II у своїй першій енцикліці зазначив, що «людина не уловлює жодних інших значень навколишнього природного середовища, крім тих, які служать цілям безпосереднього використання і постійного споживання» [4, с. 287]. Концепція захисту навколишнього середовища розглядалась як необхідність захистити природу не лише як дарунок Бога, а й задля захисту своєї людської сутності від можливості прояву майбутніх природніх катаклізмів.

Активно відбувався розвиток питання екологічної освіти і у сфері міжнародного права. У 1972 р. у Стокгольмі була підписана Декларація Конференції Організації Об'єднаних Націй з проблем навколишнього середовища, яка закріпила 26 основних принципів з питань екології. Зокрема, було проголошено право людини на свободу, рівність і благополучні умови для життя, необхідність осо- 
бливої відповідальності людини за збереження та раціональне управління продуктами живої природи. Встановився принцип суверенного права держав розробляти свої природні ресурси, принцип відповідальності за завдання шкоди довкіллю та принцип співробітництва держав задля охорони та покращення навколишнього середовища. Даний документ також закріпив необхідність прагнення держав до ядерного роззброєння та знищення будь-якої зброї масового ураження [5]. Стокгольмську Декларацію можна вважати першим міжнародним документом, який закріпив і офіційно визнав необхідність і початок співпраці держав в екологічній сфері. Її основні концепції були підтверджені у Декларації Ріо-де-Жанейро щодо навколишнього середовища та розвитку 1992 р.

У 1975р. була підписана Белградська Хартія, яка основною метою екологічної освіти визначила:

- формування обізнаності та стурбованості щодо економічної, політичної, екологічної взаємозалежності в сільській та міській місцевостях;

- створення умов для набуття кожною людиною знань, цінностей, розвитку ставлення, обов `язку та вмінь, потрібних для захисту та збереження навколишнього середовища;

- розвиток нового рівня поведінки окремих індивідів, груп людей та суспільства по відношенню до довкілля [6, с. 91-92].

Твердження про необхідність інтеграції екологічної освіти у всю систему формальної освіти на всіх рівнях задля забезпечення необхідних знань, розумінь, цінностей та навичок закріплено і в Тбіліській декларації 1977 р. Даний документ наголошує на розвитку й неформальної освіти, яка, за допомогою засобів масової інформації, сприятиме широкому поширенню обізнаності та розуміння. «Кінцева мета екологічної освіти полягає в тому, щоб дозволити людям зрозуміти складність навколишнього середовища та потребу нації, щоб адаптувати свою діяльність і продовжувати свій розвиток у спосіб, гармонійний з навколишнім середовищем» [7]. Відповідно, методи екологічної освіти мають повністю відповідати потребам сучасного суспільства, мусять бути спрямованими на залучення широкої громадськості, осіб різних вікових категорій. Формами співробітництва держав у сфері екологічної освіти є: розширення програм з питань екологічної освіти, стимулювання навчання в екологічних дослідженнях, організація семінарів, в тому числі із залученням зарубіжних вчених та інвесторів, видання журналу з екологічної освіти; організація конкурсів на виготовлення навчальних матеріалів, сприяння використанню засобів масової інформації, надання допомоги країнам, що розвиваються, у сфері екологічної освіти [7].

Охоплюючи не лише екологічну, а й інформаційну міжнародну сферу Орхуська Конвенція 2005 р. закріпила «право на доступ до інформації, на участь громадськості в процесі прийняття рішень і на доступ до правосуддя 3 питань, що стосуються навколишнього середовища» [8]. Важливим аспектом даної Конвенції стало встановлення права вільного, безкоштовного доступу до екологічної інформації в найкоротші терміни, обов'язку держав-учасників надсилати звіт щодо екологічного стану, можливість залучати громадськість до підготовки різних нормативно-правових актів, що стосуються навколишнього середовища.

Активний розвиток сфери екологічної освіти проявляється в діяльності багатьох держав світу. Зокрема, як зазначає О.П. Мягченко, у Норвегії працівники дитячих садків зобов'язані знати основи екології та охорони природи, володіти методиками екологічної освіти і виховання. В Данії, Швеції та Англії проблеми екології обов'язково вивчаються в рамках дисциплін з географії, хімії, біології фізики та історії. Також, в цих державах поширене активне створення «живих куточків», що сприяє більшому залученню не лише дорослих, а й дітей до важливості проблеми екології. У Нідерландах під контролем уряду здійснюється проект з охорони ландшафтів [9]. Австрія, в свою чергу, займається організацією великої кількості шкільних проектів з екології, проводить природоохоронні акції, видає журнали та газети з питань екологічної освіти. Франція у сфері навколишнього середовища застосовує природній, соціологічний та гуманітарний підходи, залучаючи громадськість до розгляду даної проблеми проводячи відповідні акції, благодійні заходи, розповсюджуючи інформацію у засобах масової інформації. Активно держави Свропи підтримують озеленення власних територій, що особливо спостерігається в тенденціях Швеції та Норвегії.

У 2002 р. Міністерством освіти і науки Швеції разом із Міністерством охорони навколишнього середовища цієї країни за завданням Європейської економічної комісії ООН розроблено проект «Стратегії освіти з еколого-збалансованого розвитку й екологічної освіти ЄЕК ООН». У 2003 році спеціальними робочими групами СЕК ООН закладено теоретичні основи стратегії щодо освіти задля стійкого розвитку та намічено шляхи їі реалізації [10].

Україна у сфері екологічної освіти в останні роки також досягла певного успіху. Зокрема, у 2001 р. було прийнято Закон України «Про концепцію екологічної освіти в Україні», який зазначає, що «розвиток екологічної освіти має відбуватись на основі синтезу трьох основних підходів (тенденцій), що сьогодні існують: тенденції формування сучасних екологічних уявлень, тенденції форму- 
вання нового ставлення до природи і тенденції формування нових стратегій та технологій взаємодії 3 природою» [11]. Даний документ наголошує на необхідності комплексного підходу до екологічної освіти, що охоплюватиме не лише формальну освіту (розгляд проблематики навколишнього середовища в школах та вищих навчальних закладах), а передбачатиме й вивчення екологічної сфери «за допомогою планових занять, засобів масової інформації (телебачення, радіо, газет, журналів, брошур, електронних засобів), організації постійно діючих стаціонарних і тимчасових та пересувних фотовиставок екологічного змісту, екологічних фестивалів (шкільних, університетських, молодіжних), олімпіад, конкурсів, організації тематичних екологічних науково-популярних лекцій силами різних товариств з охорони довкілля та громадських екологічних організацій, товариства "Знання", співробітників Міністерства екології та природних ресурсів України, Академій наук, викладачів вищих навчальних закладів та співробітників тощо. Крім того неформальній екологічній освіті населення мають сприяти театри, кіно, краєзнавчі музеї, релігійні установи, зоопарки, природничо-заповідні об'єкти, туристично-краєзнавчі організації» [11].

Важливим етапом у сфері екологічного права стало прийняття у 2015 р. Закону України «Про Стратегію сталого розвитку «Україна - 2020», що закріпив створення плану розвитку здорового способу життя та довкілля і вказав, що «особливу увагу потрібно приділити безпеці життя та здоров'я людини, що неможливо без ефективної медицини, захищеності соціально вразливих верств населення, безпечного стану довкілля і доступу до якісної питної води, безпечних харчових продуктів та промислових товарів» [12]. Разом з тим, не дивлячись на важливість даного кроку, Закон жодним чином не закріпив конкретні механізми розвитку екологічної освіти та захисту навколишнього середовища, в наслідок чого постає питання ефективності прийняття даного нормативно-правового акту. Таким чином, в Україні запроваджується лише видимість занепокоєнням даною проблемою.

Отже, проаналізувавши підходи різних держав до питання екологічної освіти можна зазначити, що тенденція запобігання забрудненню навколишнього середовища і активного впровадження наукових освітніх еко-програм розвивається з кожним роком. Для підвищення екологічної свідомості використовуються засоби масової інформації, радіо, телебачення та преса. Активно проводяться багато позакласних або неформальних заходів, що включають екскурсії, навчальні поїздки та польові дослідження, які проводять молодіжні асоціації, клуби, політичні рухи та профспілки.

Розуміння важливості екологічної освіти на міжнародній арені проявляється у підписанні відповідних договорів, розробці міжнародних екологічних програм, залучення інвестицій задля підвищеності свіченості населення.

Таким чином, саме комплексний підхід становить основу подальшого розвитку екологічної освіти, охоплюючи найбільш розповсюджені сфери суспільства, дозволивши залучити до даного питання громадськість всіх вікових категорій.

1. Папа Римський Франциск. Енцикліка Laudato si ' - Про турботі про спільному домі / Папа Римський Франциск. - Москва: Францисканців, 2015. - 192 с.

2. Апостольське послання Octogesima adveniens від 14 травня 1971 р., 21: AAS 63 (1971). - $416-417$ с.

3. Послання до Дня молитви про збереження творіння від1 вересня 2012 р.

4. Енцикліка Redemptor hominis від 4 березня 1979 р., 15: AAS 71 (1979). - 287 с.

5. Декларація Конференції Організації Об'єднаних Націй з проблем оточуючого людину середовища №995_454 від 16.06.1972 р. - [Електронний ресурс]: Режим доступу: https://zakon.rada.gov. ua/laws/show/995_454.

6. Свистак-Яроцька О.Л. Теорія екологічної освіти: від елементарних знань про природу до складової освіти для сталого розвитку суспільства / / Педагогіка та психологія. [Електронний ресурс]. - 2017. - Вип. 56. - С. 86-99. - Режим доступу: http://nbuv.gov.ua/UJRN/znpkhnpu_ped_2017_56_12.

7. Major environmental problems in contemporary society: Intergovernmental Conference on Environmental Education. (1977). Paris: UNESCO. - [Електронний ресурс]: Режим доступу: httр:// www.gdrc.org/uem/ee/EE-Tbilisi_1977.pdf.

8. Конвенція про доступ до інформації, участь громадськості в процесі прийняття рішень та доступ до правосуддя з питань, що стосуються довкілля (Орхуська конвенція) № 994_015 від 27.05.2005 - [Електронний ресурс]: Режим доступу: https://zakon.rada.gov.ua/laws/show/994_015.

9. Мягченко О. П. Безпека життєдіяльності людини та суспільства : навч. посіб. / О.П. Мягченко. - Київ : Центр учбової літератури, 2010.- 384 с.

10. Основи екології: Підручник.- 2-ге вид. [Текст] / Г.О. Білявський, Р.С. Фурдуй, І.Ю. Костіков. - К. : Либідь, 2005. - 408 с. 
11. Закон України «Про концепцію екологічної освіти в Україні» №v6-19290-01 від 20.12.2001 [Електронний ресурс]: Режим доступу: https://zakon.rada.gov.ua/rada/show/v6-19290-01

12. Закон України «Про Стратегію сталого розвитку «Україна - 2020» №5/2015 від 12.01 .2015 [Електронний ресурс]: Режим доступу: https://zakon.rada.gov.ua/laws/show/5/2015

\section{Summary}

The article analyses international treaties and other sources in which the problems of ecology are identified and the need to integrate ecological education into the whole system of formal and informal education at all levels. The legislation of different states concerning the tendency for prevention of environmental pollution and the active introduction of scientific educational eco-programs are investigated. The concept of environmental protection and the need for ecological education by representatives of religion are presented. It is noted that this integrated approach forms the basis for the further development of environmental education, in particular in Ukraine, covering the most widespread areas of society, allowing the public to be involved in this issue.

The article deals with the international legal regulation of issues of environmental education. The peculiarities of the development of environmental problems for decades and approaches to the ecological education of various states, including Ukraine are investigated and analyzed in detail therein.

At the present stage of the effective development and globalization of international relations in the field of environmental law, the problem of environmental pollution, which is most often manifested in the release of toxic industrial wastes into the reservoirs, pollution of the atmosphere by harmful substances, as well as the active use of polyethylene, continues to confront the world community. These factors adversely affect not only the environment but also the health of all humanity. In order to prevent catastrophic impacts on the environment, it is first and foremost to improve the effectiveness of environmental education. The trend towards prevention of environmental pollution and active implementation of scientific educational ecoprograms is developing every year. The media, radio, television and press are used to raise environmental awareness. Many extracurricular or informal activities are being actively pursued, including field trips, study visits and fieldwork conducted by youth associations, clubs, political movements and trade unions. Understanding the importance of environmental education in the international arena is reflected in the signing of relevant treaties, the development of international environmental programs, attracting investment to increase the population's luminosity. Thus, it is the most integrated approach that forms the basis for the further development of environmental education, encompassing the most widespread spheres of society, allowing the involvement of the public of all ages. 